\title{
Preparation of trichloro- and tribromocyclopentadienyltungsten(IV)
}

\author{
Haley Blackburn a, James C. Fettinger a, Heinz-Bernhard Kraatz ${ }^{\text {a,1 }}$, Rinaldo Poli b,*, \\ Raymund C. Torralba ${ }^{\text {a }}$ \\ a Department of Chemistry and Biochemistry, University of Maryland, College Park, MD 20742, USA \\ ${ }^{\mathrm{b}}$ Laboratoire de Synthèse et d'Electrosynthèse Organométalliques, Université de Bourgogne, 6 Boulevard Gabriel, F-21100 Dijon, France
}

Received 20 March 1999; accepted 19 May 1999

Dedicated to Professor Fausto Calderazzo in recognition of his outstanding contribution to organometallic chemistry.

\begin{abstract}
The thermal decarbonylation of (Ring) $\mathrm{WX}_{3}(\mathrm{CO})_{2}$ in refluxing toluene has led to the preparation of the CO-free compounds $\left[(\text { Ring }) W_{3}\right]_{2}\left[\operatorname{Ring}=\eta^{5}-\mathrm{C}_{5} \mathrm{H}_{5}(\mathrm{Cp})\right.$ and $\mathrm{X}=\mathrm{Cl}(\mathbf{1} \mathbf{a})$ or $\mathrm{Br}(\mathbf{1 b})$; $\operatorname{Ring}=\eta^{5}-\mathrm{C}_{5} \mathrm{H}_{4} \mathrm{Me}(\mathrm{Cp}), \mathrm{X}=\mathrm{Cl}(\mathbf{2 a})$ or $\mathrm{Br}(\mathbf{2 b})$; $\operatorname{Ring}=\eta^{5}$ $\left.\mathrm{C}_{5} \mathrm{Me}_{5}\left(\mathrm{Cp}^{*}\right), \mathrm{X}=\mathrm{Cl}(3)\right]$. The NMR properties of these molecules are consistent with diamagnetism and thereby indicate a different structure from that of the paramagnetic molybdenum analogues. Compounds 1a and 2a react with dppe to afford mononuclear 18-electron adducts, $(\operatorname{Ring}) \mathrm{WCl}_{3}(\mathrm{dppe})\left(\mathrm{Ring}=\mathrm{Cp}(\mathbf{4})\right.$ or $\left.\mathrm{Cp}^{\prime}(\mathbf{5})\right)$. The X-ray structure of $\mathbf{5}$ shows a pseudo-fac-octahedral geometry with the dppe ligand occupying two equatorial (e.g. cis relative to $\mathrm{Cp}^{\prime}$ ) coordination sites. The $\mathrm{X}$-ray structure of two by-products of the synthetic processes are also reported, e.g. $\mathrm{Cp}_{3}^{\prime} \mathrm{W}_{3} \mathrm{Cl}_{3}\left(\mu_{2}-\mathrm{Cl}\right)_{2}\left(\mu_{3}-\mathrm{O}\right)(6)$ and $\left[\mathrm{Cp}^{*} \mathrm{WCl}_{3}\right]_{2}(\mu-\mathrm{O})(7)$. (C) 2000 Elsevier Science S.A. All rights reserved.
\end{abstract}

Keywords: CO-free compounds; Diamagnetism; Metal-metal bonds; Tungsten; X-ray structures

\section{Introduction}

Monoyclopentadienylmetal halide systems are excellent synthons to a variety of other organometallic compounds [1]. For the heavier Group 6 metals (Mo and $\mathrm{W})$, systems with the metal in the oxidation states $\mathrm{V}$, (Ring) $\mathrm{MX}_{4}(\mathrm{Ring}=\mathrm{Cp}$ or substituted analogue) [2-5], and III, [(Ring) $\left.\mathrm{MX}_{2}\right]_{2}[5-8]$, have been known for some time. The corresponding systems of Mo(IV), $\left[(\text { Ring }) \mathrm{MoX}_{3}\right]_{2}$, have been more recently developed [913]. Here, we report on the corresponding development of the previously unknown systems of W(IV). These systems have attracted our attention not only because of their potential utility as starting compounds for further organometallic transformations, but also for

\footnotetext{
* Corresponding author. Tel.: + 33-380-396-881; fax: + 33-380396-098.

E-mail address: poli@u-bourgogne.fr (R. Poli)

${ }^{1}$ Present address: Department of Chemistry, University of Saskatchewan, Saskatoon, SK S7N 5C9, Canada.
}

their structural and bonding features. Compounds of Mo and W having the same stoichiometry are not always necessarily isostructural. This is exemplified by the structure of $\left[\left(\eta^{5}-\mathrm{C}_{5} \mathrm{H}_{4}{ }^{i} \mathrm{Pr}\right) \mathrm{MCl}_{2}\right]_{2}$ (type $\mathbf{I}$ [6] for $\mathrm{M}=\mathrm{Mo}$ and type $\mathbf{I I}$ [7] for $\mathrm{M}=\mathrm{W}$ ). The $\mathrm{W}$ compound has a tendency to maximize the metal-metal bonding at the expense of metal-ligand bonding. The structure of $\left[\mathrm{Cp}^{*} \mathrm{MoX}_{3}\right]_{2}(\mathrm{X}=\mathrm{Cl}, \mathrm{Br})$ was shown to be of type III with no direct metal-metal bonding interaction and the compounds show magnetic properties consistent with antiferromagnetic coupling between two $S=1 \mathrm{~d}^{2}$ metal centers $[11,12]$. This structure is also found for the corresponding $\mathrm{d}^{1}-\mathrm{d}^{1} \mathrm{Ta}(\mathrm{IV})$ system, $\left[\left(\eta^{5}-\right.\right.$ $\left.\left.\mathrm{C}_{5} \mathrm{Me}_{4} \mathrm{Et}\right) \mathrm{TaBr}_{3}\right]_{2}$ [14], which similarly has no metalmetal bond. However, the corresponding $\mathrm{d}^{3}-\mathrm{d}^{3}$ $\left[\left(\eta^{5}-\mathrm{C}_{5} \mathrm{Me}_{4} \mathrm{Et}\right) \mathrm{ReCl}_{3}\right]_{2}$ is diamagnetic and adopts a different structure, i.e. IV, with a metal-metal bonding interaction. We have previously advanced the hypothesis [11] that an analogous compound of W(IV) could adopt a structure analogous to that of the Re system, since $\mathrm{W}$ is known to form stronger metal-metal bonds 
than Mo. In this contribution, we present a simple synthetic procedure for the preparation of these W(IV) systems and the structure of their phosphine addition products. The diamagnetism found for $\left[(\text { Ring }) \mathrm{WX}_{3}\right]_{2}$ suggest that they indeed adopt a metal-metal bonded structure. The high oxophilicity of these materials leads to the formation of oxygen-containing by-products, two of which have been crystallographically characterized and are also described here.

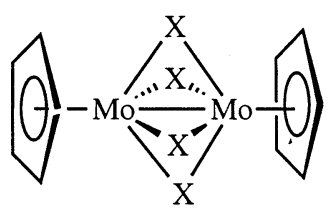

I

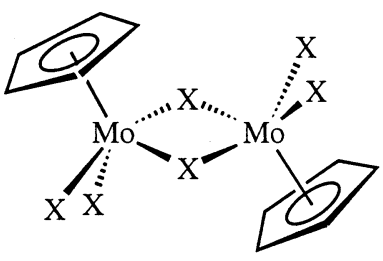

III

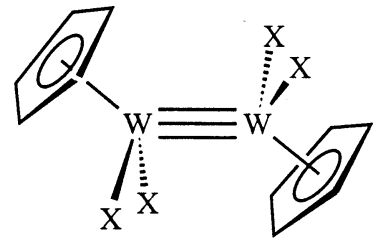

II

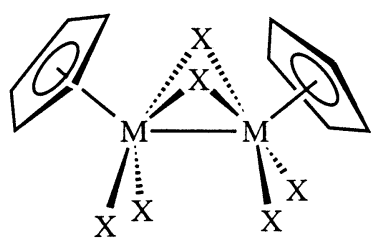

IV

\section{Experimental}

\subsection{General data}

All operations were carried out under an atmosphere of argon with standard Schlenk-line techniques. All glassware was silylated with a $1: 10 \mathrm{v} / \mathrm{v}$ solution of dichlorodimethylsilane in $\mathrm{CCl}_{4}$. Solvents were distilled directly from the drying agent (toluene and heptane from $\mathrm{Na}$, THF from $\mathrm{Na} / \mathrm{K} /$ benzophenone, $\mathrm{CH}_{2} \mathrm{Cl}_{2}$ from $\mathrm{P}_{4} \mathrm{O}_{10}$ ) under argon prior to use. FT-IR spectra were recorded with $\mathrm{KBr}$ cells on a Perkin-Elmer 1800 spectrophotometer. NMR spectra were recorded on Bruker WP200, AF200, and AM400 spectrometers; the peak positions are reported with positive shifts downfield of TMS as calculated from the residual solvent peaks $\left({ }^{1} \mathrm{H}\right)$, or downfield of external $85 \% \mathrm{H}_{3} \mathrm{PO}_{4}$ $\left({ }^{31} \mathrm{P}\right)$. For each ${ }^{31} \mathrm{P}-\mathrm{NMR}$ spectrum a sealed capillary containing $\mathrm{H}_{3} \mathrm{PO}_{4}$ was immersed in the same NMR solvent used for the measurement and this was used as the reference. The elemental analyses were carried out by M-H-W Laboratories, Phoenix, AZ, Galbraith Laboratories, Knoxville, TN, and Desert Analytics Laboratory, Tucson, AZ. Compounds $\left(\eta^{5}\right.$-Ring $) \mathrm{WX}_{3}(\mathrm{CO})_{2}$ (Ring $=\mathrm{C}_{5} \mathrm{H}_{5}, \mathrm{C}_{5} \mathrm{H}_{4} \mathrm{Me}, \mathrm{C}_{5} \mathrm{Me}_{5} ; \mathrm{X}=\mathrm{Cl}, \mathrm{Br}$ ) were prepared as previously described [15]. Dppe (Strem) was used without any further purification.
2.2. Thermal decarbonylation of $\left(\eta^{5}\right.$-Ring $) W X_{3}(C O)_{2}$ (Ring $=\mathrm{C}_{5} \mathrm{H}_{5}, \mathrm{C}_{5} \mathrm{H}_{4} \mathrm{Me} ; \mathrm{X}=\mathrm{Cl}, \mathrm{Br}$ ). Formation of $\left[\left(\eta^{5} \text {-Ring }\right) W X_{3}\right]_{2}$

The products of these reactions are only sparingly soluble in all common solvents and cannot be easily recrystallized. The spectroscopic and analytical data have been obtained for the crude materials and have been tabulated in Table 1.

(a) $\left[\left(\eta^{5}-\mathrm{C}_{5} \mathrm{H}_{5}\right) \mathrm{WCl}_{3}\right]_{2}(\mathbf{1 a}) \cdot\left(\eta^{5}-\mathrm{C}_{5} \mathrm{H}_{5}\right) \mathrm{WCl}_{3}(\mathrm{CO})_{2}(534$ $\mathrm{mg}, 1.30 \mathrm{mmol}$ ) was placed in a silylated Schlenk tube equipped with a magnetic stir bar and a silylated reflux condenser. Toluene $(20 \mathrm{ml})$ was added and the resulting yellow-green slurry was refluxed for $3 \mathrm{~h}$, yielding a dark emerald-green slurry. An IR spectrum on an aliquot of the mother solution showed no carbonyl stretching frequencies. The solution was evaporated under reduced pressure to ca. $2-3 \mathrm{ml}$ and the precipitation of the product was completed by the addition of heptane $(50 \mathrm{ml})$. After filtration, the solid was washed with heptane $(3 \times 10 \mathrm{ml})$ until the washings were colorless. The washings were cannulated off and discarded. The solid was then dried under vacuum and stored in flame-sealed vials under dinitrogen. An IR spectrum on the residual solid showed no $\mathrm{CO}$ stretching vibrations. Yield: $463 \mathrm{mg}(87 \%)$.

(b) $\left[\left(\eta^{5}-\mathrm{C}_{5} \mathrm{H}_{4} \mathrm{Me}\right) \mathrm{WCl}_{3}\right]_{2}$ (2a). By a procedure identical with that described in the preceding section, $\left(\eta^{5}\right.$ $\left.\mathrm{C}_{5} \mathrm{H}_{4} \mathrm{Me}\right) \mathrm{WCl}_{3}(\mathrm{CO})_{2}(525 \mathrm{mg}, 1.24 \mathrm{mmol})$ gave $442 \mathrm{mg}$ of product $(84 \%)$.

An identical reaction with similar quantities of all materials was performed. After the reflux in toluene, the solution was filtered and cooled to $-20^{\circ} \mathrm{C}$, affording a few dark-green crystals. A single crystal of this batch was used for the $\mathrm{X}$-ray analysis, revealing the trinuclear by-product $\left(\eta^{5}-\mathrm{C}_{5} \mathrm{H}_{4} \mathrm{Me}\right)_{3} \mathrm{~W}_{3} \mathrm{Cl}_{5} \mathrm{O}(\mathbf{6})$.

(c) $\left[\left(\eta^{5}-\mathrm{C}_{5} \mathrm{H}_{5}\right) \mathrm{WBr}_{3}\right]_{2}(\mathbf{1 b}) .\left(\eta^{5}-\mathrm{C}_{5} \mathrm{H}_{5}\right) \mathrm{WBr}_{3}(\mathrm{CO})_{2}$ was prepared in situ from $\left[\left(\eta^{5}-\mathrm{C}_{5} \mathrm{H}_{5}\right) \mathrm{W}(\mathrm{CO})_{3}\right]_{2}(1.04 \mathrm{~g}, 1.56$ $\mathrm{mmol})$ and $\mathrm{Br}_{2}(242 \mu \lambda, 4.69 \mathrm{mmol})$ in a silylated

Table 1

Spectroscopic and analytical data for $\left[\left(\eta^{5}-\mathrm{Ring}\right) \mathrm{WX}_{3}\right]_{2}$

\begin{tabular}{llll}
\hline Compound & ${ }^{1} \mathrm{H}-\mathrm{NMR} \delta(\mathrm{ppm})$ & $\begin{array}{l}\text { Elemental analyses \% found } \\
\text { (\% calculated) }\end{array}$ \\
\cline { 3 - 4 } & & $\mathrm{C}$ & $\mathrm{H}$ \\
\hline$\left[\mathrm{CpWCl}_{3}\right]_{2}$ & $5.58(\mathrm{~s})^{\mathrm{a}}$ & $16.9(16.9)$ & $1.4(1.4)$ \\
{$\left[\mathrm{CpWBr}_{3}\right]_{2}$} & $5.62(\mathrm{~s})^{\mathrm{a}}$ & $11.9(12.3)$ & $1.0(1.0)$ \\
{$\left[\mathrm{Cp}^{\prime} \mathrm{WCl}_{3}\right]_{2}$} & $5.72(\mathrm{br}, 2 \mathrm{H})^{\mathrm{b}}$ & $19.7(19.5)$ & $1.8(1.9)$ \\
& $5.31(\mathrm{br}, 2 \mathrm{H})$ & & \\
& $1.74(\mathrm{~s}, 3 \mathrm{H})$ & & \\
{$\left[\mathrm{Cp}^{\prime} \mathrm{WBr}_{3}\right]_{2}$} & $6.51(\mathrm{br}, 2 \mathrm{H})^{\mathrm{b}}$ & $14.8(14.3)$ & $1.5(1.4)$ \\
& $6.07(\mathrm{br}, 2 \mathrm{H})$ & & \\
& $1.95(\mathrm{~s}, 3 \mathrm{H})$ & &
\end{tabular}

\footnotetext{
${ }^{\mathrm{a}}$ Solvent $=\mathrm{CD}_{2} \mathrm{Cl}_{2}$.

${ }^{\mathrm{b}}$ Solvent $=\mathrm{C}_{6} \mathrm{D}_{6}$.
} 
Schlenk tube as described above in (a). The Schlenk tube was then equipped with a magnetic stir bar and a silylated reflux condenser. Toluene $(20 \mathrm{ml})$ was added and the resulting brown-yellow slurry was refluxed overnight, yielding a red-brown slurry. An IR spectrum on an aliquot of the mother solution showed no carbonyl stretching frequencies. The solution was evaporated under reduced pressure to ca. 2-3 $\mathrm{ml}$. The precipitation of the product was completed by the addition of heptane $(50 \mathrm{ml})$. The solid was washed with heptane $(3 \times 10 \mathrm{ml})$ until the washings were colorless, dried under vacuum, and stored in flame-sealed vials under dinitrogen. An IR spectrum on the residual brown solid did not show $\mathrm{CO}$ stretching vibrations. Yield: $434 \mathrm{mg}(57 \%)$.

(d) $\left[\left(\eta^{5}-\mathrm{C}_{5} \mathrm{H}_{4} \mathrm{Me}\right) \mathrm{WBr}_{3}\right]_{2}(\mathbf{2 b})$. By a procedure identical with that described in (a) above, $\left(\eta^{5}\right.$ $\left.\mathrm{C}_{5} \mathrm{H}_{4} \mathrm{Me}\right) \mathrm{WBr}_{3}(\mathrm{CO})_{2}(283 \mathrm{mg}, 0.507 \mathrm{mmol})$ gave 160 $\mathrm{mg}$ of brown solid $(63 \%)$.

\subsection{Thermal decarbonylation of $\left(\eta^{5}-\mathrm{C}_{5} \mathrm{Me}_{5}\right) \mathrm{WCl}_{3}$ - $(\mathrm{CO})_{2}$. Formation of $\left[\left(\eta^{5}-\mathrm{C}_{5} \mathrm{Me}_{5}\right) \mathrm{WCl}_{3}\right]_{2}(\mu-\mathrm{O})$ (7)}

$\left(\eta^{5}-\mathrm{C}_{5} \mathrm{Me}_{5}\right) \mathrm{WCl}_{3}(\mathrm{CO})_{2}(352 \mathrm{mg}, 0.731 \mathrm{mmol})$ was placed in a silylated Schlenk tube equipped with a magnetic stir bar and a silylated reflux condenser. Toluene $(20 \mathrm{ml})$ was added and the resulting dark-yellow slurry was refluxed for $3 \mathrm{~h}$, yielding a dark olivegreen slurry. An IR spectrum on an aliquot of the mother solution showed no carbonyl stretching frequencies. After evaporation to dryness at reduced pressure, the residue was extracted with dichloromethane affording an emerald-green solution and an olive-green residue. The olive-green residue was sparingly soluble in toluene and moderately soluble in dichloromethane. ${ }^{1} \mathrm{H}-\mathrm{NMR}\left(\mathrm{CD}_{2} \mathrm{Cl}_{2}\right): \delta 2.24$ (s). The emerald-green solution was evaporated to dryness under reduced pressure and redissolved in toluene. The solution was heated to reflux and filtered while hot. The filtrate was allowed to cool slowly to room temperature affording dark greenblack crystals. Yield: $64 \mathrm{mg} .{ }^{1} \mathrm{H}-\mathrm{NMR}\left(\mathrm{CD}_{2} \mathrm{Cl}_{2}\right): \delta 1.30$ $(\mathrm{s}) ;\left(\mathrm{C}_{6} \mathrm{D}_{6}\right) \delta 1.73(\mathrm{~s})$. A single crystal of this batch was used for the X-ray analysis.

\subsection{Reaction between $\left[\left(\eta^{5} \text {-Ring }\right) W C l_{3}\right]_{2}\left(\right.$ Ring $=C_{5} H_{5}$, $\left.\mathrm{C}_{5} \mathrm{HMe}\right)$ and dppe. Formation of $\left(\eta^{5}-\mathrm{Ring}\right) \mathrm{WCl}_{3}($ dppe $)$}

(a) $\left(\eta^{5}-\mathrm{C}_{5} \mathrm{H}_{5}\right) \mathrm{WCl}_{3}(\mathrm{dppe})(4) \cdot\left[\left(\eta^{5}-\mathrm{C}_{5} \mathrm{H}_{5}\right) \mathrm{WCl}_{3}\right]_{2}$ (358 $\mathrm{mg}, 1.01 \mathrm{mmol}$ ) was placed in a Schlenk tube with 20 $\mathrm{ml}$ dichloromethane and to the resulting green suspension was added solid dppe (402 $\mathrm{mg}, 1.01 \mathrm{mmol})$. The Schlenk tube was equipped with a reflux condenser and magnetic stir bar and the mixture was refluxed for $3 \mathrm{~h}$. The starting material dissolved to yield a dark-brown solution. An aliquot of this solution was evaporated to dryness and the residue was redissolved in $\mathrm{CD}_{2} \mathrm{Cl}_{2}$ and investigated by ${ }^{1} \mathrm{H}-\mathrm{NMR}$ spectrometry. ${ }^{1} \mathrm{H}-\mathrm{NMR}$ $\left(\mathrm{CD}_{2} \mathrm{Cl}_{2}\right): \delta 8.33-7.34(\mathrm{~m}, \mathrm{Ph}, 20 \mathrm{H}), 4.85(\mathrm{t}, \mathrm{Cp}, 5 \mathrm{H}$, $J_{\mathrm{PH}}=4 \mathrm{~Hz}$ ), 3.41 (br, $\left.\mathrm{CH}_{2}, 2 \mathrm{H}\right), 2.77$ (br, $\left.\mathrm{CH}_{2}, 2 \mathrm{H}\right)$; ${ }^{31} \mathrm{P}-\mathrm{NMR}\left(\mathrm{CD}_{2} \mathrm{Cl}_{2}\right): \delta 12.14\left(\mathrm{~s},{ }^{1} J_{\mathrm{PW}}=229 \mathrm{~Hz}\right)$.

(b) $\left(\eta^{5}-\mathrm{C}_{5} \mathrm{H}_{4} \mathrm{Me}\right) \mathrm{WCl}_{3}$ (dppe) (5). By using a procedure identical with that described above for the corresponding $\mathrm{Cp}$ compound, $\left[\left(\eta^{5}-\mathrm{C}_{5} \mathrm{H}_{4} \mathrm{Me}\right) \mathrm{WCl}_{3}\right]_{2}(610 \mathrm{mg}$, $1.65 \mathrm{mmol})$ and dppe $(658 \mathrm{mg}, 1.65 \mathrm{mmol})$ yielded a brown solution, from which $925 \mathrm{mg}$ of crude product $(79 \%)$ was obtained after filtration, evaporation to ca. 5 $\mathrm{ml}$, and addition of pentane $(50 \mathrm{ml}) .{ }^{1} \mathrm{H}-\mathrm{NMR}$ $\left(\mathrm{CD}_{2} \mathrm{Cl}_{2}\right): \delta 7.70-7.27$ (m, Ph, 20H), 4.44 (br, $\left.\mathrm{Cp}^{\prime}, 4 \mathrm{H}\right)$, 3.47 (br, $\left.\mathrm{CH}_{2}, 2 \mathrm{H}\right), 3.11$ (br, $\left.\mathrm{CH}_{2}, 2 \mathrm{H}\right), 2.17$ (s, $\mathrm{Cp}^{\prime}$, $3 \mathrm{H}) ;{ }^{31} \mathrm{P}-\mathrm{NMR}\left(\mathrm{CD}_{2} \mathrm{Cl}_{2}\right): \delta 12.96\left(\mathrm{~s},{ }^{1} J_{\mathrm{PW}}=226 \mathrm{~Hz}\right) . \mathrm{A}$ single crystal of this compound was obtained by slow diffusion of an $n$-pentane layer into a $\mathrm{CH}_{2} \mathrm{Cl}_{2}$ solution.

\subsection{X-ray crystallography}

(a) Compound 5. A dark-red parallelepiped crystal with dimensions $0.20 \times 0.20 \times 0.40 \mathrm{~mm}$ was placed on the Enraf-Nonius CAD-4 diffractometer. The cell parameters and crystal orientation matrix were determined from 25 reflections in the range $6.1<\theta<13.9^{\circ}$ and confirmed with axial photographs. Data were collected $\left[\mathrm{Mo}-\mathrm{K}_{\alpha}\right]$ with $\omega-2 \theta$ scans over the $\theta$ range $1.6-22.5^{\circ}$ with a scan width of $(1.26+1.05 \tan \theta)^{\circ}$ and a fixed scan speed of $4.12^{\circ} \mathrm{min}^{-1}$ with each scan recorded in 96 steps with the outermost 16 steps on each end of the scan being used for background determination. No decay correction was necessary $(<3 \%$ decay). Intensity statistics clearly favored the non-centrosymmetric case. The structure was determined by direct methods with the successful location of the tungsten atom in the space group $P 2_{1}$. Subsequent difference-Fourier maps revealed the location of all remaining non-hydrogen atoms within the main molecule and also the two methylene chloride molecules in the asymmetric unit. Hydrogen atoms were placed in calculated positions as described in section (a) above. After convergence, a final difference-Fourier map exhibited three peaks in the vicinity, i.e. within $1.2 \AA$, of

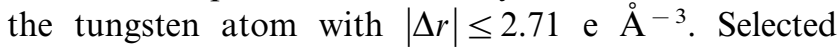
crystal data and refinement parameters are collected in Table 2, and relevant bond distances and angles are listed in Table 3.

(b) Compound 6. A black crystal with dimensions $0.13 \times 0.08 \times 0.08 \mathrm{~mm}$ was placed and optically centered on the Enraf-Nonius CAD-4 diffractometer. The cell parameters and crystal orientation matrix were determined from 25 reflections in the range $8.6<\theta<$ $20.7^{\circ}$ and confirmed with axial photographs. Data collection and reduction was carried out as described in (a) above. Two forms of data were collected in the hemisphere $\pm h k \pm l$, resulting in the measurement of 5392 reflections, 2707 of which were unique. Minor (1-4\%) 
Crystal data for all compounds

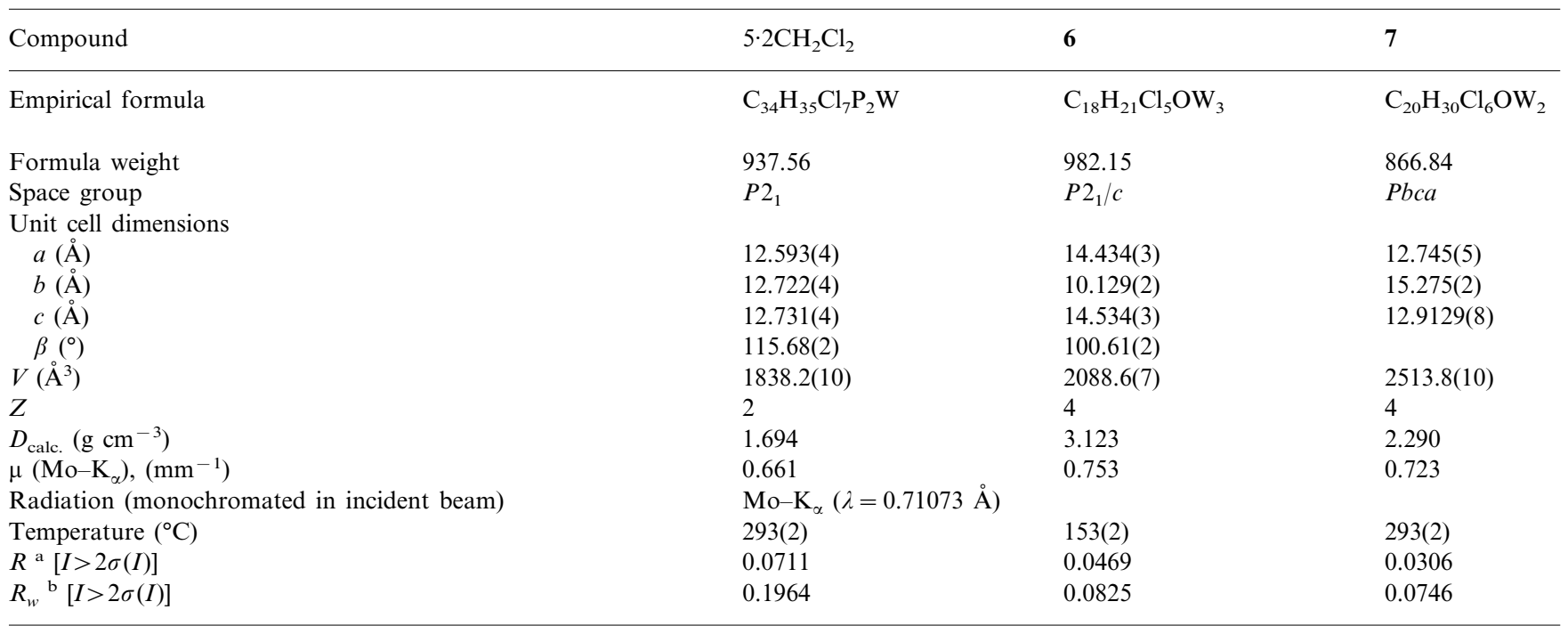

${ }^{\text {a }} R=\Sigma|| F_{\mathrm{o}}|-| F_{\mathrm{c}}|| / \Sigma\left|F_{\mathrm{o}}\right|$.

${ }^{\mathrm{b}} R_{w}=\left[\Sigma w\left(\left|F_{\mathrm{o}}\right|-\left|F_{\mathrm{c}}\right|\right)^{2} / \Sigma w\left|F_{\mathrm{o}}\right|^{2}\right]^{1 / 2} ; w=1 / \sigma^{2}\left(\left|F_{\mathrm{o}}\right|\right)$.

variations in intensity were observed for three nearly orthogonal standard reflections monitored at 1-h intervals of X-ray exposure, thus the data were not corrected for decay. The data were corrected for Lorentz and polarization factors, and for absorption on the basis of the $\psi$-scan method. Intensity statistics clearly determined the centrosymmetric monoclinic space group $P 2_{1} / c$ (no. 14). The structure was solved by direct methods with the successful location of the three tungsten atoms. Subsequent difference-Fourier maps revealed the location of all remaining non-hydrogen atoms within the molecule. Hydrogen atoms were placed in calculated positions, with the aromatic hydrogens at $\mathrm{d}(\mathrm{C}-\mathrm{H})=0.950 \AA$ and $\mathrm{U}_{\mathrm{H}}=1.2 \mathrm{U}$ (parent) while methyl hydrogens were initially determined with a rotational Fourier about the central carbon atom that was further optimized for tetrahedral geometry with $\mathrm{d}(\mathrm{C}-\mathrm{H})=0.980 \AA$ and $\mathrm{U}_{\mathrm{H}}=1.5 \mathrm{U}$ (parent). After convergence, a final difference-Fourier map exhibited several peaks in the vicinity, i.e. within $1.2 \AA$ of the tungsten atoms with $|\Delta \rho| \leq 1.58$ e $\AA^{-3}$. Selected crystal data and refinement parameters are collected in Table 2 , and relevant bond distances and angles are listed in Table 4.

(c) Compound 7. A reddish-black crystal with dimensions $0.20 \times 0.20 \times 0.25 \mathrm{~mm}$ was placed on the Enraf-Nonius CAD-4 diffractometer. The cell parameters and crystal orientation matrix were determined from 25 reflections in the range $12.9<\theta<15.2^{\circ}$ and confirmed with axial photographs. Data collection and reduction was carried out as described in (a) above. No decay correction was necessary ( $<3 \%$ decay). Systematic absences clearly indicated the centrosymmetric space group Pbca (no. 61). The structure was deter- mined by direct methods with the successful location of the tungsten and chlorine atoms. Subsequent differenceFourier maps revealed the location of all remaining non-hydrogen atoms within the molecule. Hydrogen atoms were inserted and handled as described in the previous section. After convergence, a final differenceFourier map possessed three peaks in the vicinity, i.e. within $1.2 \AA$ of the tungsten atom with $|\Delta \rho| \leq 1.29 \mathrm{e}$ $\mathrm{A}^{-3}$ and the largest remaining peaks had $|\Delta \rho| \leq 0.65 \mathrm{e}$ $\mathrm{A}^{-3}$. Selected crystal data and refinement parameters are collected in Table 2, and relevant bond distances and angles are listed in Table 5.

Table 3

Selected bond distances $(\AA)$ and bond angles $\left(^{\circ}\right)$ for compound $5 \cdot 2 \mathrm{CH}_{2} \mathrm{Cl}_{2}$

$\begin{array}{lrlr}\begin{array}{l}\text { Bond distances }(\AA) \\ \mathrm{W}(1)-\mathrm{Cl}(1)\end{array} & 2.456(8) & \mathrm{W}(1)-\mathrm{C}(2) & 2.50(3) \\ \mathrm{W}(1)-\mathrm{Cl}(2) & 2.429(7) & \mathrm{W}(1)-\mathrm{C}(3) & 2.35(3) \\ \mathrm{W}(1)-\mathrm{Cl}(3) & 2.490(9) & \mathrm{W}(1)-\mathrm{C}(4) & 2.22(3) \\ \mathrm{W}(1)-\mathrm{P}(1) & 2.570(8) & \mathrm{W}(1)-\mathrm{C}(5) & 2.19(3) \\ \mathrm{W}(1)-\mathrm{P}(2) & 2.567(8) & \mathrm{W}(1)-\mathrm{C}(6) & 2.31(3) \\ \mathrm{W}(1)-\mathrm{CNT}(1) & 2.000(3) & & \\ & & & \\ \text { Bond angles }\left({ }^{\circ}\right) & & & \\ \mathrm{Cl}(1)-\mathrm{W}(1)-\mathrm{Cl}(2) & 80.8(3) & \mathrm{Cl}(2)-\mathrm{W}(1)-\mathrm{CNT} & 175.3(9) \\ \mathrm{Cl}(1)-\mathrm{W}(1)-\mathrm{Cl}(3) & 84.1(3) & \mathrm{Cl}(3)-\mathrm{W}(1)-\mathrm{P}(1) & 153.8(3) \\ \mathrm{Cl}(1)-\mathrm{W}(1)-\mathrm{P}(1) & 89.0(3) & \mathrm{Cl}(3)-\mathrm{W}(1)-\mathrm{P}(2) & 93.6(3) \\ \mathrm{Cl}(1)-\mathrm{W}(1)-\mathrm{P}(2) & 150.7(4) & \mathrm{Cl}(3)-\mathrm{W}(1)-\mathrm{CNT} & 101.5(9) \\ \mathrm{Cl}(1)-\mathrm{W}(1)-\mathrm{CNT} & 103.9(9) & \mathrm{P}(1)-\mathrm{W}(1)-\mathrm{P}(2) & 80.2(3) \\ \mathrm{Cl}(2)-\mathrm{W}(1)-\mathrm{Cl}(3) & 79.5(3) & \mathrm{P}(1)-\mathrm{W}(1)-\mathrm{CNT} & 104.6(9) \\ \mathrm{Cl}(2)-\mathrm{W}(1)-\mathrm{P}(1) & 74.5(3) & \mathrm{P}(2)-\mathrm{W}(2)-\mathrm{CNT} & 105.2(9) \\ \mathrm{Cl}(2)-\mathrm{W}(1)-\mathrm{P}(2) & 70.1(3) & & \\ \end{array}$


Selected bond distances $(\AA)$ and bond angles $\left(^{\circ}\right)$ for $\mathrm{Cp}_{3}^{\prime} \mathrm{W}_{3} \mathrm{Cl}_{7} \mathrm{O}$

\begin{tabular}{|c|c|c|c|}
\hline \multicolumn{4}{|l|}{ Bond distances $(\AA)$} \\
\hline $\mathrm{W}(1)-\mathrm{W}(2)$ & $2.7466(12)$ & $\mathrm{W}(2)-\mathrm{Cl}(2)$ & $2.412(4)$ \\
\hline $\mathrm{W}(1)-\mathrm{W}(3)$ & $2.7741(11)$ & $\mathrm{W}(2)-\mathrm{Cl}(12)$ & $2.459(5)$ \\
\hline $\mathrm{W}(1)-\mathrm{Cl}(1)$ & $2.438(5)$ & $\mathrm{W}(2)-\mathrm{O}(123)$ & $2.036(12)$ \\
\hline $\mathrm{W}(1)-\mathrm{Cl}(12)$ & $2.491(5)$ & $\mathrm{W}(2)-\mathrm{C}(\mathrm{CNT} 2)$ & $1.973(9)$ \\
\hline $\mathrm{W}(1)-\mathrm{Cl}(13)$ & $2.488(5)$ & $\mathrm{W}(3)-\mathrm{Cl}(3)$ & $2.404(5)$ \\
\hline $\mathrm{W}(1)-\mathrm{O}(123)$ & $2.010(11)$ & $\mathrm{W}(3)-\mathrm{Cl}(13)$ & $2.445(5)$ \\
\hline $\mathrm{W}(1)-\mathrm{C}(\mathrm{CNT} 1)$ & $2.004(7)$ & $\mathrm{W}(3)-\mathrm{O}(123)$ & $2.030(12)$ \\
\hline $\mathrm{W}(2)-\mathrm{W}(3)$ & $2.6114(12)$ & $\mathrm{W}(3)-\mathrm{C}(\mathrm{CNT} 3)$ & $2.018(8)$ \\
\hline \multicolumn{4}{|l|}{ Bond angles $\left({ }^{\circ}\right)$} \\
\hline W(2)ñW(1)ñW(3) & $56.46(3)$ & $\mathrm{W}(3)-\mathrm{W}(2)-\mathrm{O}(123)$ & $49.9(3)$ \\
\hline $\mathrm{W}(2) \tilde{n} W(1) \tilde{n} C l(1)$ & $119.82(12)$ & $\mathrm{W}(3)-\mathrm{W}(2)-\mathrm{CNT} 2$ & $114.2(3)$ \\
\hline $\mathrm{W}(2) \tilde{n} W(1) \tilde{n} C l(12)$ & $55.75(11)$ & $\mathrm{Cl}(2)-\mathrm{W}(2)-\mathrm{Cl}(12)$ & $90.41(16)$ \\
\hline $\mathrm{W}(2) \tilde{n} W(1) \tilde{n} C l(13)$ & $109.12(12)$ & $\mathrm{Cl}(2)-\mathrm{W}(2)-\mathrm{O}(123)$ & $81.4(3)$ \\
\hline W(2)ñW(1)ñO(123) & $47.6(3)$ & $\mathrm{Cl}(2)-\mathrm{W}(2)-\mathrm{CNT} 2$ & 109.1(3) \\
\hline W(2)ñW(1)ñ CNT1 & $120.5(3)$ & $\mathrm{Cl}(12)-\mathrm{W}(2)-\mathrm{O}(123)$ & $76.3(3)$ \\
\hline $\mathrm{W}(3) \tilde{n} \mathrm{~W}(1) \tilde{n} \mathrm{Cl}(1)$ & $120.70(11)$ & $\mathrm{Cl}(12)-\mathrm{W}(2)-\mathrm{CNT} 2$ & $114.8(3)$ \\
\hline $\mathrm{W}(3)-\mathrm{W}(1)-\mathrm{Cl}(12)$ & $110.29(11)$ & $\mathrm{O}(123)-\mathrm{W}(2)-\mathrm{CNT} 2$ & $163.9(4)$ \\
\hline $\mathrm{W}(3)-\mathrm{W}(1)-\mathrm{Cl}(13)$ & $55.05(12)$ & $\mathrm{W}(1)-\mathrm{W}(3)-\mathrm{W}(2)$ & $61.24(3)$ \\
\hline $\mathrm{W}(3)-\mathrm{W}(1)-\mathrm{O}(123)$ & $46.9(3)$ & $\mathrm{W}(1)-\mathrm{W}(3)-\mathrm{Cl}(3)$ & $94.72(12)$ \\
\hline $\mathrm{W}(3)-\mathrm{W}(1)-\mathrm{CNT} 1$ & $119.5(2)$ & $\mathrm{W}(1)-\mathrm{W}(3)-\mathrm{Cl}(13)$ & $56.52(11)$ \\
\hline $\mathrm{Cl}(1)-\mathrm{W}(1)-\mathrm{Cl}(12)$ & $81.67(16)$ & $\mathrm{W}(1)-\mathrm{W}(3)-\mathrm{O}(123)$ & $46.3(3)$ \\
\hline $\mathrm{Cl}(1)-\mathrm{W}(1)-\mathrm{Cl}(13)$ & $82.46(16)$ & $\mathrm{W}(1)-\mathrm{W}(3)-\mathrm{CNT} 3$ & $158.4(3)$ \\
\hline $\mathrm{Cl}(1)-\mathrm{W}(1)-\mathrm{O}(123)$ & $85.2(4)$ & $\mathrm{W}(2)-\mathrm{W}(3)-\mathrm{Cl}(3)$ & $112.27(14)$ \\
\hline $\mathrm{Cl}(1)-\mathrm{W}(1)-\mathrm{CNT} 1$ & $110.6(3)$ & $\mathrm{W}(2)-\mathrm{W}(3)-\mathrm{Cl}(13)$ & $115.08(11)$ \\
\hline $\mathrm{Cl}(12)-\mathrm{W}(1)-\mathrm{Cl}(13)$ & $146.21(15)$ & $\mathrm{W}(2)-\mathrm{W}(3)-\mathrm{O}(123)$ & $50.1(3)$ \\
\hline $\mathrm{Cl}(12)-\mathrm{W}(1)-\mathrm{O}(123)$ & $76.0(3)$ & $\mathrm{W}(2)-\mathrm{W}(3)-\mathrm{CNT} 3$ & $114.5(2)$ \\
\hline $\mathrm{Cl}(12)-\mathrm{W}(1)-\mathrm{CNT} 1$ & $106.7(3)$ & $\mathrm{Cl}(3)-\mathrm{W}(3)-\mathrm{Cl}(13)$ & $89.79(17)$ \\
\hline $\mathrm{Cl}(13)-\mathrm{W}(1)-\mathrm{O}(123)$ & 73.1(4) & $\mathrm{Cl}(3)-\mathrm{W}(3)-\mathrm{O}(123)$ & $140.7(3)$ \\
\hline $\mathrm{Cl}(13)-\mathrm{W}(1)-\mathrm{CNT} 1$ & $106.8(3)$ & $\mathrm{Cl}(3)-\mathrm{W}(3)-\mathrm{CNT} 3$ & $105.9(3)$ \\
\hline $\mathrm{O}(123)-\mathrm{W}(1)-\mathrm{CNT} 1$ & $164.2(4)$ & $\mathrm{Cl}(13)-\mathrm{W}(3)-\mathrm{O}(123)$ & $73.8(3)$ \\
\hline $\mathrm{W}(1)-\mathrm{W}(2)-\mathrm{W}(3)$ & $62.30(3)$ & $\mathrm{Cl}(13)-\mathrm{W}(3)-\mathrm{CNT} 3$ & $116.1(3)$ \\
\hline $\mathrm{W}(1)-\mathrm{W}(2)-\mathrm{Cl}(2)$ & $121.35(12)$ & $\mathrm{O}(123)-\mathrm{W}(3)-\mathrm{CNT} 3$ & $113.4(4)$ \\
\hline $\mathrm{W}(1)-\mathrm{W}(2)-\mathrm{Cl}(12)$ & $56.85(11)$ & $\mathrm{W}(1)-\mathrm{Cl}(12)-\mathrm{W}(2)$ & $67.40(13)$ \\
\hline W(1)ñW(2)ñO(123) & $46.8(3)$ & $\mathrm{W}(1)-\mathrm{Cl}(13)-\mathrm{W}(3)$ & $68.43(13)$ \\
\hline $\mathrm{W}(1)-\mathrm{W}(2)-\mathrm{CNT} 2$ & $128.0(3)$ & $\mathrm{W}(1)-\mathrm{O}(123)-\mathrm{W}(3)$ & $86.7(4)$ \\
\hline $\mathrm{W}(3)-\mathrm{W}(2)-\mathrm{Cl}(2)$ & $108.34(12)$ & $\mathrm{W}(1)-\mathrm{O}(123)-\mathrm{W}(2)$ & $85.5(5)$ \\
\hline $\mathrm{W}(3)-\mathrm{W}(2)-\mathrm{Cl}(12)$ & $116.98(12)$ & $\mathrm{W}(2)-\mathrm{O}(123)-\mathrm{W}(3)$ & $79.9(4)$ \\
\hline
\end{tabular}

\section{Results and discussion}

\subsection{Synthesis and physical properties}

The preparation of the trihalocyclopentadienyltungsten(IV) compounds follows one of the strategies previously adopted for the synthesis of the corresponding Mo(IV) compounds [10-12], i.e. thermal decarbonylation of the dicarbonyl adducts, see Eq. (1). The latter compounds are easily available by dihalogen oxidation of the corresponding $\left[(\mathrm{Ring}) \mathrm{W}(\mathrm{CO})_{3}\right]_{2}$ compounds [15].

(Ring) $\mathrm{WX}_{3}(\mathrm{CO})_{2} \underset{\text { toluene }}{\stackrel{\Delta}{\longrightarrow}} 1 / 2\left[(\text { Ring }) \mathrm{WX}_{3}\right]_{2}+2 \mathrm{Co}$

$\left(\mathrm{Ring}=\mathrm{Cp}, \mathrm{Cp}^{\prime} ; \mathrm{X}=\mathrm{Cl}, \mathrm{Br}\right)$

The occurrence of a complete decarbonylation of these tungsten carbonyl derivatives, albeit under rather forcing conditions (refluxing toluene as com- pared with refluxing $\mathrm{CH}_{2} \mathrm{Cl}_{2}$ for the Mo systems), is somewhat remarkable because the strength of the $\mathrm{M}-\mathrm{CO}$ bond increases upon descending a group of transition metals. For instance, while thermal decarbonylation of $\mathrm{MoI}_{2}(\mathrm{CO})_{3}(\mathrm{dppm})$ cleanly affords $\mathrm{Mo}_{2} \mathrm{I}_{4}(\mathrm{dppm})_{2}$ [16], the corresponding $\mathrm{WI}_{2}(\mathrm{CO})_{3^{-}}$ $(\mathrm{dppm})$ affords only $\mathrm{WI}_{2}(\mathrm{CO})(\mathrm{dmpm})_{2}$ in small yields [17].

The solubility of the $\mathrm{W}(\mathrm{IV})$ trichloride products increases, as expected, in the order $\mathrm{Cp}<\mathrm{Cp}^{\prime} .{ }^{1} \mathrm{H}-\mathrm{NMR}$ characterization for the $\mathrm{Cp}$ compounds could only be carried out in dilute $\mathrm{CD}_{2} \mathrm{Cl}_{2}$ solutions, whereas the $\mathrm{Cp}^{\prime}$ derivatives are sufficiently soluble in aromatic hydrocarbons. The ${ }^{1} \mathrm{H}-\mathrm{NMR}$ properties of the isolated materials (see Table 1) indicate diamagnetism, in contrast with the corresponding Mo analogues [11,12], this hinting to a different structure for the Mo and $\mathrm{W}$ analogues (see Section 1). Unfortunately, suitable single crystals could not be obtained for any of these derivatives. During one of the various crystallization attempts, crystals of an oxygenated by-product were obtained for the $\mathrm{Cp}^{\prime}$-chloro system $\left(\mathrm{Cp}_{3}^{\prime} \mathrm{W}_{3} \mathrm{Cl}{ }_{5} \mathrm{O}\right.$, compound 6). The structure of this compound, showing several remarkable features, is discussed later. It is noteworthy that oxygen incorporation in these systems is associated with formal metal reduction. We have not been able to elucidate the nature of the concomitant oxidation products.

In an attempt to facilitate the crystallization process, the synthesis of the more methyl-substituted (thus presumably more soluble) $\mathrm{Cp}^{*}$-chloro derivative was attempted by the same decarbonylation method shown in Eq. (1). Indeed, the decarbonylation of $\mathrm{Cp}^{*} \mathrm{WCl}_{3}(\mathrm{CO})_{2}$ yielded an intensely colored green solution, which contains two diamagnetic products according to ${ }^{1} \mathrm{H}-\mathrm{NMR}$ spectroscopy. The major product could be obtained in the form of single crystals and was shown by $\mathrm{X}$-ray crystallography to correspond to the oxo compound $\left[\mathrm{Cp}^{*} \mathrm{WCl}_{3}\right]_{2} \mathrm{O}$ (7), vide infra. This result was reproduced several times, in spite of our best attempts to rigorously exclude air and moisture (see Section 2). The oxygen atom could be originating from a $\mathrm{CO}$ ligand by a process of metal-mediated $\mathrm{CO}$ bond breaking, which is not unprecedented for tungsten $[18,19]$. If this is the case, a carbido ligand could possibly be incorporated into the other observed product which, unfortunately, could not be obtained in a pure, crystalline form suitable to full characterization [20].

For the less methyl-substituted $\mathrm{Cp}$ and $\mathrm{Cp}^{\prime}$ systems, only a single compound could be detected by ${ }^{1} \mathrm{H}$ NMR investigations of the crude products and satisfactory $\mathrm{C}, \mathrm{H}$ analyses were obtained. The identity of the compounds is further confirmed by the derivatization reactions discussed in the next section. 
3.2. Formation of ligand adducts and $X$-ray structure of $\mathrm{Cp}^{\prime} \mathrm{WCl}_{3}($ dppe $)$

Compounds $\left[\mathrm{CpWCl}_{3}\right]_{2}$ and $\left[\mathrm{Cp}^{\prime} \mathrm{WCl}_{3}\right]_{2}$ slowly add dppe in refluxing dichloromethane, to afford the 18electron adducts, see Eq. (2):

$\left[(\text { Ring }) \mathrm{WCl}_{3}\right]_{2}+2 \mathrm{dppe} \rightarrow 2$ (Ring) $\mathrm{WCl}_{3}($ dppe $)$

$\left(\right.$ Ring $\left.=\mathrm{Cp}, \mathbf{4} ; \mathrm{Cp}^{\prime}, \mathbf{5}\right)$

These reactions show that the $\mathrm{W}-\mathrm{W}$ bonds in these systems are sufficiently weak to allow their rupture and the formation of mononuclear ligand adducts. However, the reactions are quite slow when compared with those of the corresponding [(Ring) $\left.\mathrm{MoCl}_{3}\right]_{2}$ complexes in which the metal centers are held together only by two bridging chloride ligands $[9,11]$. Both products of reaction 2 are diamagnetic compounds and are stoichiometric analogues of the previously reported $\mathrm{CpMoCl}_{3}(\mathrm{dppe})$, which was shown to adopt the pseudo-mer-octahedral structure $\mathbf{V}$ in the solid state [21]. The same stereochemistry was also established for compound $\mathrm{CpMoCl}_{3}(\mathrm{dmpe})$ [22]. The NMR properties of the $\mathrm{W}$ derivatives, however, indicate equivalence for the two $\mathrm{P}$ nuclei (singlet resonance in the ${ }^{31} \mathrm{P}-\mathrm{NMR}$ spectrum and triplet resonance for the $\mathrm{Cp}$ protons in the ${ }^{1} \mathrm{H}-\mathrm{NMR}$ spectrum of 4) and are therefore more consistent with the alternative $f a c$ stereochemistry illustrated in VI, which is common, on the other hand, to the previously reported $\mathrm{Mo}(\mathrm{IV})$ bis-phosphite derivative $\mathrm{CpMoCl}_{3}\left[\mathrm{P}\left(\mathrm{OCH}_{2}\right)_{3} \mathrm{CEt}\right]_{2}$ [9], and to the W(IV) carbonyl derivatives $\left(\mathrm{C}_{5} \mathrm{H}_{4}{ }^{i} \mathrm{Pr}\right) \mathrm{WBr}_{3}(\mathrm{CO})_{2} \quad[23]$ and $\mathrm{Cp}^{*} \mathrm{WBr}_{3}(\mathrm{CO})_{2}$ [15]. The $f a c$ geometry of compound $\mathbf{5}$ has been unambiguously confirmed by an X-ray structural determination (see Fig. 1).

Table 5

Selected bond distances $(\AA)$ and bond angles $\left(^{\circ}\right)$ for $\left[\mathrm{Cp}^{*} \mathrm{WCl}_{3}\right]_{2}(\mu-\mathrm{O})$

\begin{tabular}{lc}
\hline Bond distances $(\AA)$ & \\
W-Cl(1) & $2.371(3)$ \\
W-Cl(3) & $2.372(3)$ \\
W-Cl(2) & $2.375(3)$ \\
W-CNT & $2.031(11)$ \\
W-O & $1.8709(4)$ \\
& \\
Bond angles $\left({ }^{\circ}\right)$ & \\
$\mathrm{Cl}(1)-\mathrm{W}-\mathrm{Cl}(2)$ & $80.17(11)$ \\
$\mathrm{Cl}(1)-\mathrm{W}-\mathrm{Cl}(3)$ & $139.45(12)$ \\
$\mathrm{Cl}(1)-\mathrm{W}-\mathrm{O}$ & $84.69(8)$ \\
$\mathrm{Cl}(1)-\mathrm{W}-\mathrm{CNT}$ & $110.1(3)$ \\
$\mathrm{Cl}(2)-\mathrm{W}-\mathrm{Cl}(3)$ & $79.96(12)$ \\
$\mathrm{Cl}(2)-\mathrm{W}-\mathrm{O}$ & $135.17(10)$ \\
$\mathrm{Cl}(2)-\mathrm{W}-\mathrm{CNT}$ & $112.2(3)$ \\
$\mathrm{Cl}(3)-\mathrm{W}-\mathrm{O}$ & $85.04(7)$ \\
$\mathrm{Cl}(3)-\mathrm{W}-\mathrm{CNT}$ & $110.1(3)$ \\
$\mathrm{O}-\mathrm{W}-\mathrm{CNT}$ & $112.6(2)$ \\
$\mathrm{W}-\mathrm{O}-\mathrm{W}{ }^{\prime}$ & 180.0 \\
\end{tabular}

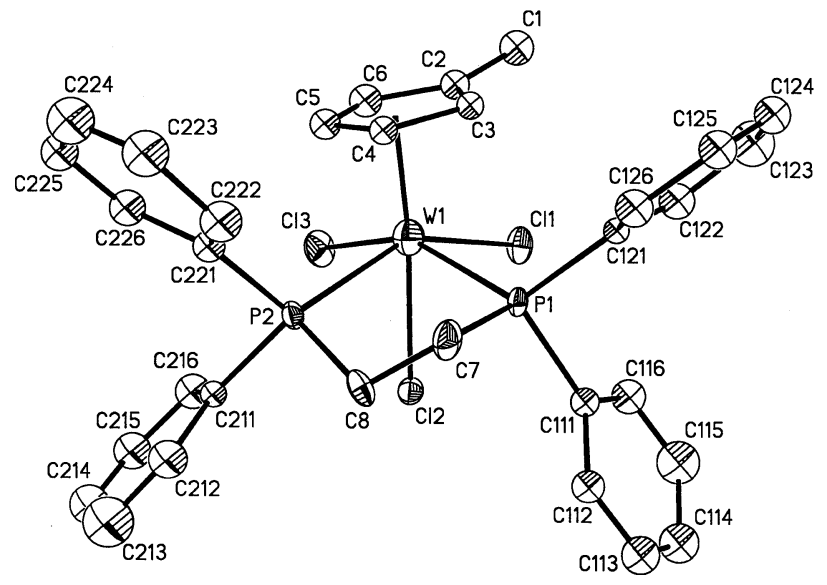

Fig. 1. A view of the molecular structure of compound $\mathrm{Cp}^{\prime} \mathrm{WCl}_{3}(\mathrm{dppe})$.

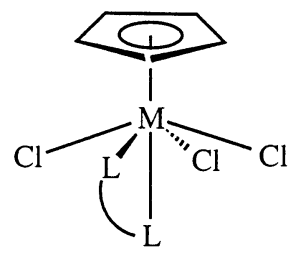

V

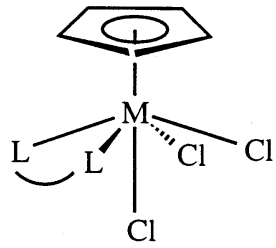

VI
Selected distances and angles are reported in Table 3. The cyclopentadienyl ring is significantly distorted from the ideal five-fold symmetry, the difference between the shortest and longest W-C distance being 0.31(4) $\AA$. The longest distance is to the methyl-substituted $\mathrm{C}$ atom $[\mathrm{W}(1)-\mathrm{C}(2), 2.50(3) \AA]$, while the shortest ones are those to the opposite $C$ atoms, C(4) and C(5), 2.22(3) and 2.19(3) $\AA$, respectively. This distortion could be induced sterically by the proximity of the ring $\mathrm{Me}$ substituent and the $\mathrm{Cl}(1)$ atom and/or electronically by the back-donation from the metal $\mathrm{d}_{x y}$ orbital to one of the ring $\delta$ acceptor orbitals, as previously described [24]. A similar distortion has been noted for $\left(\eta^{5}-\right.$ $\left.\mathrm{C}_{5} \mathrm{H}_{4}{ }^{i} \mathrm{Pr}\right) \mathrm{WBr}_{3}(\mathrm{CO})_{2}$, whose stereochemistry is identical to that of compound 6 [23]. We are not aware of other crystal structures of monocyclopentadienyltungsten(IV) chloride or phosphine derivatives. The average $\mathrm{W}-\mathrm{Cl}$ distance $[2.46(3) \AA]$ is similar to the average $\mathrm{Mo}-\mathrm{Cl}$ distance in the corresponding $\mathrm{CpMoCl}_{3}(\mathrm{dppe})[2.48(1)$ $\AA$ ] [21], $\mathrm{CpMoCl}_{3}\left[\mathrm{P}\left(\mathrm{OCH}_{2}\right)_{3} \mathrm{CEt}\right]_{2}$ [2.47(4) $\left.\mathrm{\AA}\right]$ [9], and $\mathrm{CpMoCl}_{3}(\mathrm{dmpe})$ [2.494(7) $\mathrm{A}$ ] [22] compounds. The axial (trans to $\mathrm{Cp}$ ) $\mathrm{W}-\mathrm{Cl}$ distance is slightly shorter than the equatorial (trans to $\mathrm{P}$ ) distances, as previously seen also for $\mathrm{CpMoCl}_{3}\left[\mathrm{P}\left(\mathrm{OCH}_{2}\right)_{3} \mathrm{CEt}\right]_{2}$ [9]. The $\mathrm{W}-\mathrm{P}$ distances are essentially equivalent and their average $[2.568(8) \AA]$ is similar to the average Mo-P distance in $\mathrm{CpMoCl}_{3}(\mathrm{dppe})[2.604 \AA]$ [21] and $\mathrm{CpMoCl}_{3}(\mathrm{dmpe})$ $\left[\begin{array}{ll}2.548 & \AA\end{array}\right][22]$, although in the latter cases the two 
individual distances are quite different from each other because of the different geometry (e.g. V).

The different solid state structure of the homologous $\mathrm{CpMCl}_{3}(\mathrm{dppe}$ ) compounds ( $\mathbf{V}$ for $\mathbf{M o}, \mathbf{V I}$ for $\mathbf{W}$ ) is an interesting phenomenon that does not have a clear-cut explanation. In solution, structure VI appears to be strongly favored for the $\mathrm{W}$ system (no other isomer can be detected by ${ }^{31} \mathrm{P}-\mathrm{NMR}$ ), whereas a more delicate balance is present for the Mo compound, an 80:20 mixture of isomers favoring $\mathbf{V}$ being established by ${ }^{31} \mathrm{P}-\mathrm{NMR}$ in $\mathrm{CD}_{2} \mathrm{Cl}_{2}$ [21].

\subsection{Structure of $\mathrm{Cp}_{3}^{\prime} \mathrm{W}_{3} \mathrm{Cl} \mathrm{O}_{5} \mathrm{O}$}

A view of this compound is shown in Fig. 2 and selected bond distances and angles are given in Table 4 . The structure of this molecule is quite remarkable; the three metal centers display three different coordination geometries, none of which appears to have any precedent in the literature for $\mathrm{W}$ systems. These geometries can be roughly described as a $\mathrm{Cp}^{\prime} \mathrm{WCl}_{3} \mathrm{O}$ four-legged piano stool for $\mathrm{W}(1)$ and four-coordinate (when considering the $\mathrm{Cp}^{\prime}$ ligands as occupying a single coordination geometry) $\mathrm{Cp}^{\prime} \mathrm{WCl}_{2} \mathrm{O}$ for $\mathrm{W}(2)$ and $\mathrm{W}(3)$. The geometries around $\mathrm{W}(2)$ and $\mathrm{W}(3)$ differ for the relative ligand arrangement, e.g. the $\mathrm{CNT}(2)-\mathrm{W}(2)-\mathrm{O}(123)$ and $\mathrm{CNT}(3)-\mathrm{W}(3)-\mathrm{O}(123)$ angles $[\mathrm{CNT}(n)$ is the centroid of the $\mathrm{Cp}^{\prime}$ ring attached to the $\mathrm{W}(n)$ atom] are 163.9 and $113.5^{\circ}$, respectively. The $\mathrm{W}$ atoms define an isosceles triangle, the two longer $\mathrm{W}(1)-\mathrm{W}(2)$ and $\mathrm{W}(1)-\mathrm{W}(3)$ vectors $[2.747(1)$ and 2.774(1) $\AA$, respectively] being bridged by a chlorine atom and the unique shorter W(2)-W(3) vector [2.611(1) $\mathrm{A}]$ having no bridging $\mathrm{Cl}$ atom. The oxygen atom caps the $\mathrm{W}_{3}$ triangle

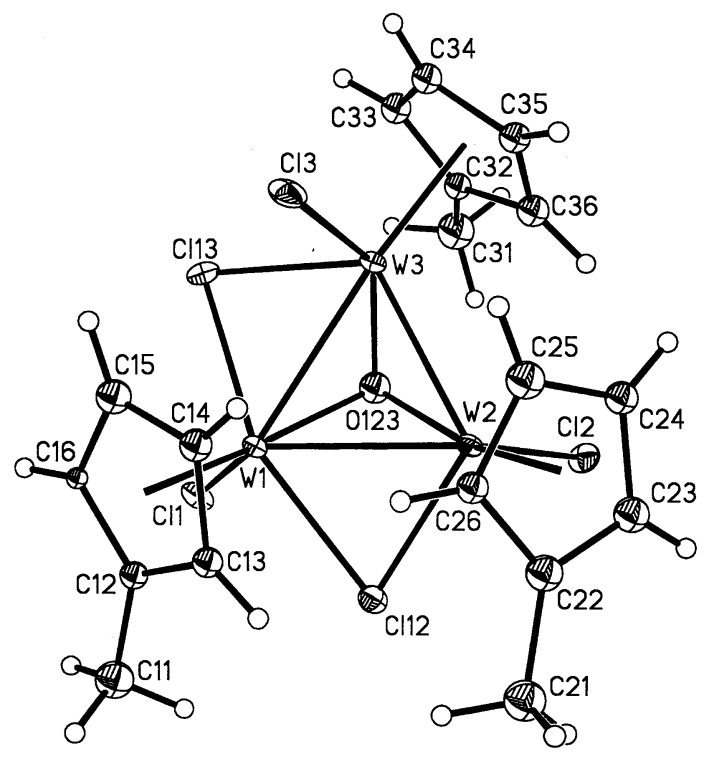

Fig. 2. A view of the molecular structure of compound $\mathrm{Cp}_{3}^{\prime} \mathrm{W}_{3} \mathrm{Cl}_{5} \mathrm{O}$.

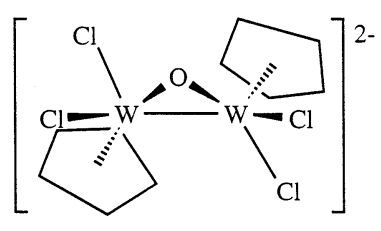

(a)

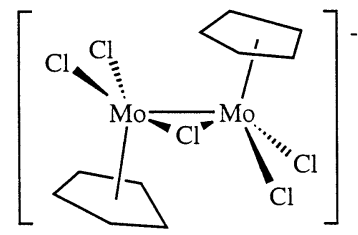

(b)
Scheme 1.

with essentially equal distances to the three $\mathrm{W}$ atoms [average 2.02(2) $\AA$ ]. The average oxidation state of the metal in this compound is 3 and $1 / 3$. A valence-trapped assignment as +4 for $\mathrm{W}(1)$ and +3 for $\mathrm{W}(2)$ and $\mathrm{W}(3)$ is indicated by the structure. Mononuclear fourlegged piano stool compounds for W(IV) (e.g. having a 16-electron configuration) are not precedented, but this is a common geometry for analogous complexes of $\mathrm{Mo}(\mathrm{IV})$, for instance $\left[\mathrm{CpMoCl}_{2} \mathrm{~L}_{2}\right]^{+}$and $\mathrm{CpMoCl}_{3} \mathrm{~L}$ ( $\mathrm{L}=$ tertiary phosphine) $[25,26]$. The two $\mathrm{d}$ electrons of the $\mathrm{W}(1)$ atom can be imagined to become involved in metal-metal bonding through participation of the $\mathrm{d}_{x y}$ orbital, which is of suitable symmetry. If, at this point, the $\mathrm{Cp}^{\prime} \mathrm{WCl}^{2+}$ unit of atom $\mathrm{W}(1)$ is removed from the cluster, the remaining fragment corresponds to a $\left[\mathrm{Cp}_{2}^{\prime} \mathrm{W}_{2} \mathrm{Cl}_{4}(\mu-\mathrm{O})\right]^{2-}$ ion as illustrated in Scheme 1(a). The geometry of this ion strongly resembles that of the dinuclear $\mathrm{Mo}(\mathrm{III})$ ion $\left[\mathrm{CpMoCl}_{4}(\mu-\mathrm{Cl})\right]^{-}$[27], shown schematically in Scheme 1(b), giving credit to our oxidation state assignment for atoms $\mathrm{W}(2)$ and $\mathrm{W}(3)$. The two geometries in Scheme 1 differ only in the relative disposition and angular relationships of the ligands (cisoid $\mathrm{Cp}^{\prime}$ and transoid terminal $\mathrm{Cl}$ ligands in the $\mathrm{W}$ structure; transoid $\mathrm{Cp}$ ligands in the Mo structure). This difference probably results from the steric repulsion between the $\mathrm{Cp}^{\prime}$ rings in the $\mathrm{Cp}_{3}^{\prime} \mathrm{W}_{3} \mathrm{Cl}_{5} \mathrm{O}$ structure and by the forced relative configuration of the $\mathrm{Cl}(12)$ and $\mathrm{Cl}(13)$ ligands, these being locked into place by the need to bridge the $\mathrm{W}(2)$ and $\mathrm{W}(3)$ atoms, respectively, with $\mathrm{W}(1)$. The $\mathrm{W}(2)-\mathrm{W}(3)$ bond is slightly longer than the Mo-Mo bond in $\left[\mathrm{Cp}_{2} \mathrm{Mo}_{2} \mathrm{Cl}_{5}\right]^{-}$[2.413(1) $\left.\mathrm{A}\right]$ [27], which was described as a weakened metal-metal triple bond. Other parallels may be drawn between the structure of $\mathbf{6}$ and other oxo-capped, trimetallic clusters such as $\mathrm{Cp}_{3} \mathrm{Mo}_{3} \mathrm{Cl}_{7} \mathrm{O}$, [28] (Ring) ${ }_{3} \mathrm{Nb}_{3} \mathrm{Cl}_{x}(\mathrm{OH})_{7-x} \mathrm{O}$ $\left(\mathrm{Ring}=\mathrm{Cp}, \quad \mathrm{Cp}^{\prime} ; \quad \mathrm{X}=\mathrm{Cl}, \quad \mathrm{OH}\right), \quad[29,30] \quad$ and $\mathrm{Cp}_{3}^{*} \mathrm{Ta}_{3} \mathrm{O}_{4} \mathrm{Cl}_{4},[31,32]$ but none of these show coordination geometries or a d-electron count as 6 .

The terminal $\mathrm{W}(1)-\mathrm{Cl}$ bond is longer than the other terminal $\mathrm{W}-\mathrm{Cl}$ bonds, contrary to what would be expected on the basis of the oxidation state assignment given above. However, while the $\mathrm{Cl}(1)$ ligand is bonded to an effectively saturated $\mathrm{W}(1)$ center, the $\mathrm{Cl}(2)$ and $\mathrm{Cl}(3)$ are bonded to electronically unsaturated metal centers. The shorter $\mathrm{W}(2)-\mathrm{Cl}(2)$ and $\mathrm{W}(3)-\mathrm{Cl}(3)$ distances may therefore reflect the involvement of some 


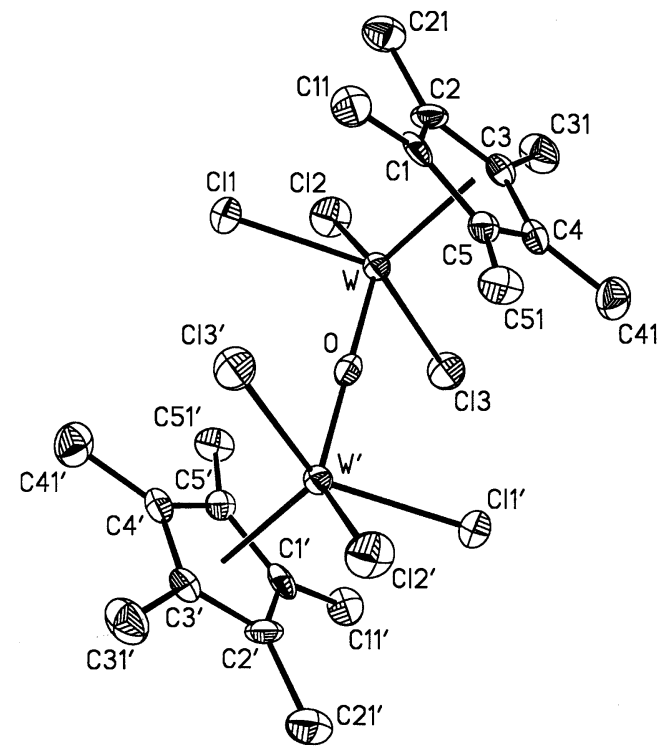

Fig. 3. A view of the molecular structure of compound $\left[\mathrm{Cp}^{*} \mathrm{WCl}_{3}\right]_{2}(\mu-$ $\mathrm{O})$.

$\mathrm{W}-\mathrm{Cl} \pi$ bonding. For the same reason, the $\mathrm{W}-\mathrm{Cl}$ distances to the bridging $\mathrm{Cl}$ ligands are shorter on the $\mathrm{W}(2)$ and $\mathrm{W}(3)$ sides with respect to the $\mathrm{W}(1)$ side. All bridging $\mathrm{W}-\mathrm{Cl}$ bonds are, as expected, longer than the terminal ones.

\subsection{Structure of $\left[\mathrm{Cp}^{*} \mathrm{WCl}_{3}\right]_{2}(\mu-\mathrm{O})$}

A view of this compound is shown in Fig. 3 and selected bond distances and angles are given in Table 5 . The compound crystallizes with the oxygen atom sitting on a center of symmetry, thus the linearity of the $\mathrm{W}-\mathrm{O}-\mathrm{W}$ moiety is crystallographically imposed. The geometry around each $\mathrm{W}$ atom is of the four-legged piano stool type, the four legs being the three terminal chlorine and the bridging $\mathrm{O}$ atoms. The three $\mathrm{W}-\mathrm{Cl}$ distances are essentially equivalent [average 2.373(3) $\mathrm{A}$ ]. These $\mathrm{W}-\mathrm{Cl}$ distances and the $\mathrm{W}-\mathrm{O}$ distance are significantly shorter than the corresponding parameters in the above described $\mathrm{Cp}_{3}^{\prime} \mathrm{W}_{3} \mathrm{Cl} \mathrm{l}_{5} \mathrm{O}$, in agreement with the higher metal oxidation state in $\left[\mathrm{Cp}^{*} \mathrm{WCl}_{3}\right]_{2} \mathrm{O}$. In addition, $\mathrm{W}-\mathrm{O}$ multiple bonding is allowed in the dinuclear $\mathrm{W}(\mathrm{V})$ compound, further shortening the bonds, whereas only $\sigma$ bonds are allowed for the capping oxygen in the trinuclear cluster described above. The $\mathrm{W}-\mathrm{O}$ distance is comparable with that of the isoelectronic $\left\{\left[\mathrm{Cp}_{2} \mathrm{~W}\left(\mathrm{CH}_{3}\right)\right]_{2}(\mu-\mathrm{O})\right\}^{2+}$ complex $(1.904(1) \AA)$ [33].

\section{Conclusions}

The study reported here has allowed us to establish the existence of the hitherto missing monocyclopentadi- enyl halides of W(IV). A comparison with the previously developed Mo systems indicates two main differences. The decarbonylation of (Ring) $\mathrm{MX}_{3}(\mathrm{CO})_{2}$ is, as expected, less facile for $\mathrm{W}$ than for Mo. It does proceed to completion, however, in refluxing toluene. The structure of the two $\left[(\operatorname{Ring}) \mathrm{MX}_{3}\right]_{3}$ systems is quite different, the lack of metal-metal bonding leading to paramagnetism for $\mathrm{M}=$ Mo whereas diamagnetic compounds, presumably containing metal-metal bonds [20], are obtained for $\mathrm{M}=\mathrm{W}$. These compounds are able, however, to add neutral donors with formation of diamagnetic mononuclear derivatives (albeit more slowly than the corresponding Mo systems), as exemplified by the formation of the dppe adducts (Ring) $\mathrm{WCl}_{3}(\mathrm{dppe}) \quad\left(\mathrm{Ring}=\mathrm{Cp}, \mathrm{Cp}^{\prime}\right) . \quad$ Finally, these W(IV) systems are quite reactive toward oxygen containing compounds, leading to the facile formation of oxygen-containing derivatives.

\section{Supplementary material}

Crystallographic data for the structural analyses have been deposited with the Cambridge Crystallographic Data Centre, CCDC No. 116644 for $\mathbf{5} \cdot 2 \mathrm{CH}_{2} \mathrm{Cl}_{2}, \mathrm{CCDC}$ No. 116646 for 6, and CCDC No. 116645 for 7. Copies of this information may be obtained free of charge from the Director, CCDC, 12 Union Road, Cambridge, CB2 1EZ, UK (Fax: + 44-1223-336033; e-mail: deposit@ccdc.cam.ac.uk or www: http://www.ccdc.cam. ac.uk).

\section{Acknowledgements}

Support of this work from the US Department of Energy-Office of Energy Research (DEFG0295ER14550) and the Région Bourgogne is gratefully acknowledged. The authors thank Dr Peter Burger for disclosing to us the results of his work on $\left[\mathrm{Cp}^{*} \mathrm{WCl}_{3}\right]_{2}$ [20].

\section{References}

[1] R. Poli, Chem. Rev. 91 (1991) 509.

[2] M. Cousins, M.L.H. Green, J. Chem. Soc. (1964) 1567.

[3] R.C. Murray, L. Blum, A.H. Liu, R.R. Schrock, Organometallics 4 (1985) 953.

[4] P.G. Sal, I. Jiménez, A. Martín, T. Pedraz, P. Royo, A. Sellés, A. Vásquez de Miguel, Inorg. Chim. Acta 273 (1998) 270.

[5] F.J. de la Mata, P. Giner, P. Royo, J. Organomet. Chem. 572 (1999) 155

[6] P.D. Grebenik, M.L.H. Green, A. Izquierdo, V.S.B. Mtetwa, K. Prout, J. Chem. Soc. Dalton Trans. (1987) 9.

[7] M.L.H. Green, J.D. Hubert, P. Mountford, J. Chem. Soc. Dalton Trans. (1990) 3793. 
[8] K. Fromm, E. Hey-Hawkins, Z. Anorg. Allg. Chem. 619 (1993) 261.

[9] R. Poli, M.A. Kelland, J. Organomet. Chem. 419 (1991) 127.

[10] J.C. Gordon, V.T. Lee, R. Poli, Inorg. Chem. 32 (1993) 4460.

[11] F. Abugideiri, G.A. Brewer, J.U. Desai, J.C. Gordon, R. Poli, Inorg. Chem. 33 (1994) 3745.

[12] J.U. Desai, J.C. Gordon, H.-B. Kraatz, V.T. Lee, B.E. OwensWaltermire, R. Poli, A.L. Rheingold, C.B. White, Inorg. Chem. 33 (1994) 3752.

[13] H.-B. Kraatz, R. Poli, J. Organomet. Chem. 475 (1994) 167.

[14] C. Ting, L. Messerle, Inorg. Chem. 28 (1989) 171.

[15] H. Blackburn, H.-B. Kraatz, R. Poli, R.C. Torralba, Polyhedron 14 (1995) 2225.

[16] F.A. Cotton, K.R. Dunbar, R. Poli, Inorg. Chem. 25 (1986) 3700.

[17] F.A. Cotton, L.R. Falvello, R. Poli, Polyhedron 6 (1987) 1625.

[18] M.H. Chisholm, D.L. Clark, J.C. Huffman, C.A. Smith, Organometallics 6 (1987) 1280.

[19] M.H. Chisholm, J. Organomet. Chem. 334 (1987) 77.

[20] (a) Dr Peter Burger (University of Zurich) has informed us that compound $\left[\mathrm{Cp}^{*} \mathrm{WCl}_{3}\right]_{2}$ has been obtained in his laboratory by sodium reduction of $\mathrm{Cp}^{*} \mathrm{WCl}_{4}$ and that its $\mathrm{X}$-ray structure is as shown in IV. (b) C. Cremer, Diplomarbeit, Universities of Kostanz and Zürich, 1996.
[21] K. Stärker, M.D. Curtis, Inorg. Chem. 24 (1985) 3006.

[22] B.E. Owens, R. Poli, Inorg. Chim. Acta 179 (1991) 229.

[23] Q. Feng, M. Ferrer, M.L.H. Green, P. Mountford, V.S.B. Mtetwa, J. Chem. Soc. Dalton Trans. (1992) 1205.

[24] P. Kubácek, R. Hoffmann, Z. Havlas, Organometallics 1 (1982) 180.

[25] S.T. Krueger, B.E. Owens, R. Poli, Inorg. Chem. 29 (1990) 2001.

[26] F. Abugideiri, J.C. Gordon, R. Poli, B.E. Owens-Waltermire, A.L. Rheingold, Organometallics 12 (1993) 1575.

[27] R. Poli, A.L. Rheingold, J. Chem. Soc. Chem. Commun. (1990) 552.

[28] A. Cole, J.C. Gordon, M.A. Kelland, R. Poli, A.L. Rheingold, Organometallics 11 (1992) 1754.

[29] M.D. Curtis, J. Real, Inorg. Chem. 27 (1988) 3176.

[30] F. Bottomley, P.N. Keizer, P.S. White, K.F. Preston, Organometallics 9 (1990) 1916.

[31] P. Jernakoff, C. de Méric de Bellefon, G.L. Geoffroy, A.L. Rheingold, S.J. Geib, Organometallics 6 (1987) 1362.

[32] P. Jernakoff, C. de Méric de Bellefon, G.L. Geoffroy, A.L. Rheingold, S.J. Geib, New J. Chem. 12 (1988) 329.

[33] P. Jernakoff, J.R. Fox, J.C. Hayes, S. Lee, B.M. Foxman, N.J. Cooper, Organometallics 14 (1995) 4493. 